\title{
The intestinal immune system
}

\author{
WILLIAM F DOE
}

(This article is one of a series linked with the Festschrift for Christopher Booth. See Gut Festschrift 1989; 30.)

The concept of localised intestinal immunity has its origins in Besredka's observation that oral immunisation using killed salmonella organisms provided solid protection against dysenteric infection irrespective of the titres of serum antibody.' But the clinical benefits were variable and short lived and interest lapsed. Little further progress was made until Heremans' discovery of IgA and the marked predominance of IgA-containing plasma cells in normal intestinal mucosa.: The differences between the antigenic determinants of serum and secretory $\operatorname{IgA}$ led to the identification of an additional polypeptide chain, the secretory component (SC), which is essential to the secretion and function of $\operatorname{IgA}$ antibody at mucosal surfaces. ${ }^{3}$

The importance of the mucosal immune system to the pathogenesis of intestinal disease was swiftly recognised by Chris Booth. When I arrived as a houseman at Hammersmith in 1969, several pioneering immunological studies of coeliac disease had been published. The clinical research ethos at Hammersmith stimulated the study of human disease not only by applying basic scientific knowledge and techniques but also by recognising that careful study of human disease can also provide opportunities for advancing our understanding of human biology. I recall the outpatient clinic in 1969 when Chris handed me the referral letter for a new patient he had not seen: 'Fascinating, sounds like alpha chain disease.'

Several months later Heremans came to Hammersmith to deliver a series of outstanding lectures on the secretory immune system. Grand rounds that week included the presentation of what was to be one of the earliest published cases of alpha chain disease. ${ }^{+}$

In the decades since these early discoveries, major advances in understanding the physiology of the intestinal immune response and the advent of molecular biology have helped to elucidate the induction and regulation of the secretory antibody and cellular responses at mucosal surfaces.

\section{Gut associated lymphoid tissue (GALT)}

The exposed surface of the intestinal mucosa is under constant challenge by ingested foreign antigens in micro-organisms, products of food digestion and drugs. It is therefore not surprising that the intestines contain the largest accumulation of lymphoid tissues in the body in the form of lymphoid aggregates in Peyer's patches and in the lamina propria (solitary lymphoid nodules) and as the scattered lymphocyte populations found in the epithelium and in the lamina propria.

Although nascent Peyer's patches are evident in the newborn, the epithelium and lamina propria are devoid of mononuclear cells. T lymphocytes migrating from the thymus rapidly populate the thymus - dependent areas of Peyer's patches and the epithelium but exposure to micro-organisms in the normal environment is necessary to develop the B cell population and their germinal follicles as shown by experiments conducted in germ free animals.

\section{Induction of the secretory immune response}

Non-immune and immune mechanisms protect the privileged environment of the lamina propria from challenge by foreign antigens. Gastric acidity, digestive proteases in the gastrointestinal tract, intestinal mobility, the commensal microflora and the mucous coat or glycocolyx comprise some of the non-specific protective barriers. The immune mechanisms may operate within the lumen of the gut, at the mucosal surface or within the lamina propria. The interepithelial lymphocyte (IEL) population are predominantly suppressor lymphocytes (Ts) in contrast with the lamina propria and show evidence of activation whereas most of the lamina propria lymphocytes belong to the helper-inducer subset (Th). Class II MHC determinants which represent a restriction element in $\mathrm{T}$ cell dependent immune responses are expressed on normal small intestinal epithelial cells but not colon epithelial cells unless the colon is inflamed. Expression of class II antigens is modulated by lymphokine products of activated $\mathrm{T}$ cells especially interferon $\gamma$ (IFN $\gamma)$. Bland and Warren ${ }^{7}$ reported that MHC class II positive villous epithelial cells can present soluble antigen to primed $T$ cells leading to antigen specific suppression. Although human colonic epithelial cells have been reported to act as stimulators in autologous and allogeneic responses ${ }^{8}$ others have been unable to stimulate $T$ cells in an allogeneic system using an MHC class II positive colon cancer cell line. ${ }^{y}$ 
Whether IEL require a second signal from accessory cells in the lamina propria remains to be answered.

Most studies of isolated GALT cells have been performed using Peyer's patch cells. Whether these reflect the function of all organised GALT is unknown. The dome of Peyer's patches is covered by a unique epithelium comprising cuboidal epithelial cells which express class II MHC antigens, very few goblet cells and specialised antigen-sampling cells called M (for microfold) cells."' M cells pinocytose soluble antigens such as ferritin and horse-radish peroxidase or phagocytose particulate foreign antigens including viruses and whole bacteria, and transport them intact across the epithelium to the underlying lymphoreticular cells in the dome."

Macrophages and dendritic cells are present in the dome region, and $\mathrm{MHC}$ class II positive cells displaying dendritic cell morphology are also found in the $\mathrm{T}$ and $\mathrm{B}$ cell zones. Dendritic cells found in cell suspensions of Peyer's patches are fully able to present antigen in vitro ${ }^{12}$ and those present in the lamina propria of the small and large intestine in mouse and man are also competent to present antigens. Whether Peyer's patch macrophages also function as antigen presenting cells, however, is uncertain, as lamina propria macrophages suppress antigen presentation by dendritic cells. ${ }^{13}$

Peyer's patches contain a higher proportion of B cells than peripheral nodes. While IgM-bearing B cells predominate, there is significant enrichment for $B$ cells displaying surface $\operatorname{Ig} A$ and committed to $\operatorname{Ig} A$ synthesis consistent with the role of GALT as a major site for the induction of IgA responses. Peyer's patches are also greatly enriched for $T$ cells of the helper-inducer subset (Th) although suppressorcytotoxic $T$ cells (Ts) and the regulatory contrasuppressor $\mathrm{T}$ cells (Tcs) which appear to potentiate immune responses to orally presented antigen, are also found. The high degree of preferential localisation of B cells and IgA specific Th cells in Peyer's patches is probably determined by the specificity of binding of these lymphocytes to the high endothelial venule receptors present in postcapillary venules in Peyer's patches ${ }^{14}$ which determine their representation in Peyer's patches and ultimately regulate the nature of the immune response generated.

Yet induction of mucosal immunity and the delivery of the immune response is not entirely localised to the intestine. After antigen exposure, Th cells and B cells committed to specific IgA synthesis are rapidly generated in Peyer's patches and travel via the mesenteric node into the thoracic duct to enter the circulation before selectively migrating to mucosal surfaces. Whether this inability to mount a completely localised immune response to antigen encountered at a mucosal surface relates to separation of the $T$ and $B$ cell zones in Peyer's patches from antigen presenting cells is not known. Mestecky and McGhee ${ }^{\text {ls }}$ have speculated that antigen presentation to lymphocytes does occur in GALT resulting in an 'initial induction' of immune responses and that the "terminal inductive stimuli' may occur at distant mucosal sites after these committed lymphocytes have migrated there.

The migratory characteristics of IgA-committed lymphoblasts and memory cells are quite distinct. Unlike memory lymphocytes, IgA-containing lymphoblasts do not recirculate but 'home' to the organ of antigenic stimulation, secrete antibody, remain associated with the mucosal target tissue and probably die within a few days. ${ }^{16}$ In rats primed and challenged by intraintestinal injection of cholera toxin, specific antibody - containing lymphoblasts were found three to five days later in the thoracic duct lymph from where they entered the circulation and then populated distant mucosal sites. The number of lymphoblasts in the thoracic duct greatly diminished after five days but the number of small lymphocytes capable of transferring specific immunity to naive animals (memory cells) peaked after two weeks and persisted. The memory cells, which will produce Tand B-lymphoblasts when stimulated by specific antigen, enter the circulation from the lymph, 'home' to distant mucosal sites and then re-enter the lymph to recirculate. ${ }^{17}$ Peripheral lymphoid tissues were not examined in these experiments but other studies suggest that memory lymphocytes from the thoracic duct also 'home' preferentially to mucosal lymphoid tissue.

Lymphocyte 'homing' is not dependent on the presence of antigen. IgA lymphoblasts migrate to fetal isografts of small intestine transplanted underneath the kidney capsule of an adult mouse. ${ }^{10}$ When rats primed by intracolonic injection of cholera toxin were challenged 14 days later by injecting antigen into a surgically isolated loop of jejunum with an intact blood and lymph supply, blast cells appeared in comparable numbers in the stimulated intestinal loop and in the unstimulated jejunum. By cannulating and draining the thoracic duct, the researchers confirmed that antigen stimulation of memory cells in the isolated jejunal loop resulted in the production of lymphoblasts that entered the lymph and circulated to populate the entire jejunum. ${ }^{17}$ Although memory cells recirculate to populate the mucosal tissues, general mucosal dissemination of lymphoblasts committed to IgA synthesis does not occur after secondary challenge. When thoracic duct lymphoblasts from animals both primed and challenged by intracolonic injection of cholera toxin were transferred into naive recipients, large numbers of antibody specific plasma cells populated the colon but there were virtually 
none found in the jejunum. These studies suggest that the lymphoblasts can distinguish between high endothelial cell receptors in the colon and jejunum indicating that the colon receptors have their own 'homing' specificity. The presence of antigen, however, profoundly affects the magnitude and persistence of the response due to antigen-driven clonal expansion of antibody forming cells and their precursors. ${ }^{\text {Ih }}$

\section{Intestinal fluid immunoglobulins}

A specialised form of $\operatorname{Ig} \mathrm{A}$, secretory $\operatorname{Ig} \mathrm{A}$, represents the predominant antibody isotype in intestinal fluid where the relative concentrations of the major immunoglobulin isotypes mirror their relative distribution in the antibody-containing cells of the intestinal mucosa. ${ }^{3}$ Unlike $\operatorname{IgA}$ in the serum and cerebrospinal fluid which largely comprises $7 \mathrm{~S}$ monomers, secretory $\operatorname{IgA}$ is an $11 \mathrm{~S}$ dimer made up of two IgA monomers joined by a covalently linked peptide named $\mathbf{J}$ chain. ${ }^{19}$ Both IgA and IgM plasma cells synthesise $\mathbf{J}$ chain which greatly enhances the binding of an additional polypeptide, secretory component (SC), thereby completing the assembly of secretory $\operatorname{IgA}$ and $\operatorname{IgM}$ molecules. The details of secretory $\operatorname{IgA}$ structure have recently been reviewed. ${ }^{15} \mathbf{J}$ chain is an acidic peptide of 137 residues which may be involved in the intracellular polymerisation of $\operatorname{IgA}$. One molecule of $\mathrm{J}$ chain joins two IgA monomers whereas three or more $\mathbf{J}$ chain molecules are involved in forming the IgM pentamer within the plasma cell before secretion.

Secretory component (SC) is a glycopeptide molecule synthesised by epithelial cells in secretory glandular tissue and mucosal surfaces. In some mammalian species, but not man, hepatocytes also synthesise and display SC. Secretory component exists in three molecular forms; as a membrane protein expressed on the outer surface of epithelial cells, it acts as a receptor for polymeric immunoglobulins. Secretory component forms part of secretory $\operatorname{IgA}$ and $\operatorname{IgM}$ molecules in mucosal fluids where it is also found as a free glycoprotein. Secretory component interacts with a specific binding site on the $\mathrm{Fc}$ region of SIgA and IgM, stabilises their quaternary structures, and increases their resistance to proteolytic digestion. ${ }^{3}$ Structural studies of human SC reveal a characteristic composition, comprising 549 to 558 amino acids and a high carbohydrate content $(20 \%)$. Twenty cysteine residues create 10 intrachain disulphide bridges in a single polypeptide chain that has five regions of remarkable homology. The fifth homology region contains an additional labile disulphide bond that is involved in the formation of a disulphide bridge linking $\mathrm{SC}$ to the two chains of one of the monomers in dimeric IgA. The homology regions of SC are structurally related to the variable domain of immunoglobulin light chains and probably have a similar tertiary structure. Since the secondary structure of $\mathbf{J}$ chain also shows immunoglobulin like folding, the interactions of $\alpha, \mu$ and $\mathrm{J}$ chains with SC may be based on the complementaries of their domain-like structures. ${ }^{21}$ Both the additional peptides SC and $\mathrm{J}$ chain bind covalently to the Fc region of $\operatorname{IgA}$ and $\mathrm{IgM}$.

The constant domains of the $\alpha$ chains of the two subclasses of $\operatorname{IgA}, \operatorname{Ig} A_{1}$ and $\operatorname{Ig} A_{2}$ are very similar. The $C$ terminus of the $\alpha$ chain resembles that of the $\mu$ chain and extends further than the $C$ termini of the $\gamma$, $\varepsilon$ and $\sigma$ chains of $\operatorname{IgG}, \operatorname{IgE}$ and $\operatorname{IgD}$ strongly suggesting that this extension is implicated in the ability of IgA and IgM to form polymers. ${ }^{\text {Is }}$

The predominant structural differences between $\operatorname{Ig} \mathrm{A}_{1}$ and $\operatorname{Ig} \mathrm{A}_{2}$ occur in the hinge region where $\operatorname{Ig} \mathrm{A}_{1}$ has a unique sequence of 13 amino acids that are susceptible to cleavage by highly specific bacterial $\operatorname{IgA}$ proteases. The corresponding sequence is lacking in $\operatorname{IgA}_{2}$ molecules which are therefore resistant to nearly all known bacterial proteases with the exception of a clostridial IgA protease that cleaves a peptide bond in the hinge region of both $\operatorname{Ig} \mathrm{A}_{1}$ and $\operatorname{IgA} \mathrm{A}_{2}$ of the $\mathrm{A} 2 \mathrm{~m}(1)$ allotype. ${ }^{21}$

Plasma cells producing $10 \mathrm{~S} \mathrm{IgA} \mathrm{are} \mathrm{found} \mathrm{in} \mathrm{all}$ mucosal tissues especially in the intestinal lamina propria whereas plasma cells in the bone marrow, spleen and peripheral lymph nodes secrete monomeric (7S) $\lg \mathrm{A}$. There is also a selective distribution of cells producing the $\operatorname{Ig} \mathrm{A}_{1}$ and $\operatorname{Ig} \mathrm{A}_{2}$ subclasses. $\operatorname{Ig} \mathrm{A}_{1}$ plasma cells form the majority in all tissues apart from the colon but there is marked variation in the ratio of $\operatorname{Ig} \mathrm{A}_{1}$ to $\operatorname{Ig} \mathrm{A}_{2}$ plasma cells between lymphoid tissues from different sites. That $\operatorname{Ig} \mathrm{A}_{2}$ is the preponderant subclass in the colon may relate to local stimulation by endotoxins from commensal gram negative organisms which mainly induce an $\operatorname{Ig} \mathrm{A}_{2}$ subclass antibody response resistant to bacterial proteases. $^{15}$

\section{Secretory IgA function}

The protective role of secretory $\operatorname{IgA}$ against a variety of foreign antigens, including food antigens bacteria viruses and toxins, is well established. S-IgA blocks the access of potentially allergenic molecules derived from food or drugs. S-IgA mediated responses at mucosal surfaces to locally encountered antigens are readily detected but prolonged topical exposure to protein or particulate antigens is required to induce serum antibodies."2 Antibodies of all three major isotypes specific for food and microbial antigens are 
detectable in the sera of normal individuals. They are mostly $\operatorname{Ig} \mathrm{A}_{1}$ class and very high serum titres are found in $\operatorname{IgA}$ deficient patients. S-IgA may also block reaginic sensitivity reactions at the surface of the intestinal epithelium as reported for nasal epithelium. Because some dietary antigen is clearly absorbed by normal subjects, the importance of S-IgA antibody may lie in reducing the amount of antigen that gains access to the lamina propria.

S-IgA can neutralise biologically active antigens, including viruses and toxins and enzymes, prevent adherence of bacterial pathogens to epithelial surfaces and enhance the antibacterial efficiency of other immune effector systems. The effectiveness of $\mathrm{S}-\operatorname{IgA}$ as a neutralising antibody against viruses is shown by the responses to the Sabin oral live poliovirus vaccine where protection correlates with levels of secretory antibody. ${ }^{23}$ The four antigen combining sites of S-IgA also allow it to function efficiently as an agglutinin and the capacity of S-IgA to protect by inhibiting bacterial adherence to the mucosal epithelium is exemplified by S-IgA antibodies to Vibrio cholera. There is also evidence that $\operatorname{IgA}$ has bacteriocidal potential in cooperation with complement and lysozyme and S-IgA can opsonise bacteria as outlined below.

Unlike IgM or IgG, however, secretory $\operatorname{Ig}$ A does not recruit the powerful mediator systems that are activated in systemic immune responses. In particular, slgA-antigen complexes do not activate the classical or alternative pathways of complement..$^{2+}$ Chemically aggregated $\operatorname{IgA}$ in high concentration does activate the alternative pathway but the biological relevance of the finding is questionable.

$\operatorname{IgA}$ and $\operatorname{IgA}$-containing immune complexes are capable of interacting with neutrophils, mononuclear phagocytes, epithelial cells lining mucous membranes, T, B and NK cells. The Fc receptors for $\mathrm{C} \alpha 2$ domain of polymeric and monomeric $\operatorname{IgA}$ and for sIgA of both subclasses that are displayed by subpopulations of neutrophils and mononuclear phagocytes increase in number when these cells are exposed to high levels of IgA. These findings may explain the enhanced phagocytic activity of mucosal neutrophils compared to those from the circulation. ${ }^{25}$ The functional significance of $F c \alpha$ receptors on phagocytes is uncertain. Earlier reports suggested that $\operatorname{IgA}$ had little capacity as an opsonin, but recent studies indicate that particles coated with $\operatorname{IgA}$ are readily phagocytosed by neutrophils from the oral cavity." Neutrophils may also clear IgA complexes from the blood. Macrophages in colostrum and milk contain large amounts of S-IgA suggesting that they provide the means for transporting $\mathrm{S}$ - IgA into the lower gastrointestinal tract of breastfed infants. There is also evidence that IgA can 'arm' neutrophils and Th cells to provide cell mediated antibacterial activity. ${ }^{2 h}$

The secretory component (SC) displayed on the basolateral membrane of mucosal epithelial cells acts as a receptor for polymeric IgA and IgM by binding to a $\mathbf{J}$ chain-related site. The SC-polymeric IgA complex is internalised by the epithelial cell and transported as a vesicle to its apical surface where the SC-IgA complex is released..$^{27}$ Although human hepatocytes do not express surface SC they do have surface membrane receptors specific for asialoglycoproteins called hepatic binding proteins that bind human polymeric $\operatorname{Ig} \mathrm{A}_{1}$ and to a lesser extent monomeric $\operatorname{Ig} \mathrm{A}_{1} \cdot \operatorname{Ig} \mathrm{A}_{2}$ does not inhibit this interaction. The human liver rapidly clears $\mathrm{S}-\operatorname{Ig} \mathrm{A}_{1}$ from the circulation indicating that the hepatic binding protein acts as a receptor for $\mathrm{S}-\operatorname{Ig} \mathrm{A}_{1}$ uptake..$^{2 \mathrm{~K}}$ Unlike those species that have hepatocytes bearing SC, humans do not transport large quantities of circulating IgA across the hepatocyte and into the bile. In human bile, only about $50 \%$ of the polymeric IgA is derived from the plasma.

\section{Regulation of S-IgA immune responses}

Many characteristics of the S-IgA system clearly distinguish it from systemic immunity. GALT contains all the cells required for local responses and is constantly exposed to antigenic stimulation and to biological active bacterial components such as endotoxin, but a number of negative regulatory factors suppress the induction of a localised immune response. There is selective priming of GALT B cells leading to marked restriction of the isotype potential of $\mathrm{B}$ cells to IgA expression. ${ }^{29}$ Endogenous gut endotoxin appears to enhance the host's resistance to gram negative infections possibly by interacting with lymphoreticular cells in GALT resulting in induction of innate host immunity to infection.

The IgA response to antigens including carbohydrate antigens is controlled by $\mathrm{T}$ cells. Peyer's patch $T$ cells stimulated by Conconavalin A help IgA expression but suppress IgM and IgG in LPS-driven B cell cultures whereas similarly treated splenic $T$ cells suppress all three isotypes. ${ }^{30}$ Oral administration of soluble or particulate antigens induces Th cells in GALT which are specific for the IgA isotype and probably account for the $\operatorname{IgA}$ isotype response that results from oral immunisation.

Two separate modes of $T$ cell regulation for the IgA response apparently exist in GALT. T cells may induce $\mathrm{B}$ cells to switch isotypes ( $\mathrm{Tsw})^{31}$ by promoting the switch of $B$ cells bearing surface $\operatorname{IgM}\left(\operatorname{sIgM}^{+}\right)$to cells expressing surface $\operatorname{IgA}(\operatorname{sg} \mathrm{A})$ - events that are influenced by factors released by activated $T$ cells including interleukins 4 and 5. A second mode of T 
cell regulation of $\mathrm{IgA}$ responses may involve Th cells bearing $F c$ receptors for $\operatorname{IgA}(\mathrm{Fc} \alpha)$ which preferentially interact with $\operatorname{sig} A^{+} B$ cells and differentiate them into IgA-producing plasma cells. ${ }^{32}$ In mice, Fc $\alpha$ receptors ( $F c \alpha R$ ) are also found on some Ts cells that can release the $F c \alpha R$ as an IgA-binding factor (IBF $\alpha$ ) resulting in suppression of IgA synthesis in pokeweed mitogen driven spleen cell cultures. On exposure to $\operatorname{Ig} \mathrm{A}$, activated $\mathrm{Fc} \alpha \mathrm{R}^{+} \mathrm{T}$ cells released $\mathrm{IBF} \alpha$ and suppressed $\operatorname{IgA}$ responses. Supernatants of $\mathrm{Fc} \alpha^{+} \mathrm{R}$ hybrids created by fusing Peyer's patch Th cells with a $T$ cell lymphoma line, supported antigen-dependent IgA responses in cultures of normal Peyer's patch B cells whereas $\mathrm{F} c \alpha \mathrm{R}^{-}$hybrid supernatants did not. When IBF $\alpha$ was purified from the supernatants, high concentrations suppressed $T$ cell-dependent IgA responses while low levels of IBF $\alpha$ enhanced IgA responses. ${ }^{33}$ These results indicate that $T$ cell selection and induction of $\operatorname{sIg} \mathrm{A}^{+} \mathrm{B}$ cells involves $\mathrm{Fc} \alpha \mathrm{R}$ and that high concentrations of IBF $\alpha$ have a paradoxical suppressor effect. Whether these effects derive from different concentrations of the same IBF $\alpha$ molecule or whether, as has been shown for IgE, there are two classes of IBF, one suppressor the other helper, that differ in their carbohydrate moieties, ${ }^{34}$ has not been established. Thus clones of $T$ cells may produce both surface Fc $\alpha$ receptors and a secretory form(s) of IBF $\alpha$ which markedly influence the responses of sIgA ${ }^{+}$cells in a complex network to generate $\operatorname{IgA}$ specific immunoregulation at exposed mucosal sites involving selective homing mechanisms for redistribution of IgA-committed cells.

\section{$T$ cell networks and oral tolerance}

Two separate immune responses follow oral administration of antigen in large doses; S-IgA antibodies are generated at mucosal surfaces and unresponsiveness to the same antigen - that is, tolerance, develops systemically. The simultaneous generation of Th and Ts cells specific for the same antigen implies another level of control which is apparently provided by the contra-suppressor T cell (Tcs). Indeed Tcs, which are enriched along with Th cells in Peyer's patches, can abolish oral tolerance when adoptively transferred to an animal orally immunised by the same antigen. IgA isotype-specific Tcs cells have recently been reported in Peyer's patches. These Tcs bind to immobilised Fc $\alpha \mathrm{R}^{+}$helper cells and, when adoptively transferred, also abolish oral tolerance. ${ }^{35}$

Although circulating immune complexes ${ }^{36}$ and anti-idiotypic antibodies ${ }^{37}$ have also been proposed as mechanisms mediating oral tolerance, the evidence suggests that a $T$ cell suppression network plays the major part in the downregulation of systemic immune responses.

\section{Mucosal cellular responses}

Studies of effector cell populations in isolated lamina propria mononuclear cells have identified marked differences in their relative frequency, functional state and phenotype in comparison to corresponding cell populations in the peripheral blood. Lamina propria lymphocytes show enhanced proliferation after exposure to interleukin 2 (IL-2), a much higher proportion of IL-2 receptor-bearing cells in the Th and Ts subpopulations and an increased proportion of $T$ cells expressing class II antigens of the major histocompatibility complex. Moreover, IL-2 receptor mRNA is detectable in unstimulated lamina propria lymphocytes. But there is no evidence of IL-2 mRNA expression. Peripheral blood lymphocytes do not express either mRNA. ${ }^{3 \times}$ Mucosal T cells therefore selectively express some of the genes associated with $T$ cell activation resulting in 'partial' activation or 'primed' mucosal T cells that may result from unique, possibly environmental activation signals in the intestine or altered regulation of $T$ cell function at mucosal surfaces.

Mucosal cell mediated cytotoxicity unrestricted by the MHC is also markedly distinct from that found in peripheral blood. Natural killer cells represent 2-3\% of dispersed lamina propria cells, as identified by the NKH-1 monoclonal antibody, but are Leu $11^{-39}$. Natural killer activity is very low or undetectable in unseparated lamina propria cells ${ }^{+1+1}$ but can be discerned in purified $\mathrm{NKH}^{-1}{ }^{+}$cells. ${ }^{3 "}$ Mucosal lymphokine activated killer (LAK) cells also express a different phenotype to those in peripheral blood being $\mathrm{T}_{1} 1^{+}, \mathrm{NKH}-1^{-}$, Leu $11^{-}, \mathrm{T}^{-}, \mathrm{T}^{-}, \mathrm{T}_{1} 1^{-}$, and $\mathrm{T} 8^{-39+1}$ and high levels of cytotoxicity to cell lines and to freshly isolated cells can be generated after exposure of lamina propria lymphocytes to IL-2 in culture for $72 \mathrm{~h} .{ }^{+1+1}$ Non-specific cytolytic cells activated by lectins which are also present may well be a variant of the LAK cell. Although the numbers and cytotoxic activity of mucosal NK cells are very limited, it remains possible that other NK cell capabilities, including resisting viral infection, and immunoregulation may be relevant to mucosal homeostasis. Lymphokine activated killer cells lyse solid tumour cells in vitro but whether the conditions exist to generate this population in vivo is unclear. Markers of $\mathrm{T}$ cell activation are markedly increased in lamina propria lymphocytes compared to those from peripheral blood. These include proliferative responses to IL-2, IL-2 receptor expression and function and expression of class II MHC antigens but there is no enhancement of IL-2 synthesis. Mucosal NK cells and other Fc-bearing cells including macrophages may mediate antibody-dependent cytotoxicity (ADCC). Antibody-dependent cytotoxicity has been 
shown in lamina propria cells but its importance to mucosal inflammation remains to be assessed.

An indirect measure of in vitro primed cytotoxic $\mathrm{T}$ cell activity that is not MHC restricted may be obtained using antibodies to the $\mathrm{CD} 3$ component of the human $\mathrm{T}$ cell receptor. ${ }^{+2}$ High levels of cytotoxicity were found in lamina propria cells from histologically normal colon possibly reflecting the exposure of the mucosa to consistent and diverse antigenic challenges. These effector cells display the $\mathrm{CD} 2^{+}, \mathrm{CD}^{+}, \mathrm{CD}^{+}, \mathrm{CD}^{-}, \mathrm{CD}^{-} 6^{-}$and Leu 7 phenotype and the pattern of target cell specificity may be determined by the CD45 antigen which is coupled to the trigger process for $\mathrm{NK}$ lysis of some target cells. ${ }^{+3}$ This cell population may represent in vitro primed cytotoxic $\mathrm{T}$ cells reactive against undetermined antigens including viruses.

\section{Conclusion}

Clinical research involving the detailed study of individual patients has made many important and original contributions to understanding of the physiology of the intestinal immune system in health and disease. In this context, the study of individual patients suffering from alpha chain disease $(\alpha C D)$ represents a paradigm. The importance of diffuse, small intestinal lymphomas called Mediterranean lymphomas (ML) as a cause of malabsorption in the Middle East had been recognised for many years, but understanding was limited to descriptive accounts of the morphology of the cellular infiltrate as seen in stained paraffin sections of intestinal tissue. When individual patients in Paris ${ }^{4+}$ and at Hammersmith ${ }^{45}$ were investigated, it was discovered that the diffuse cellular infiltrate represented a monoclonal expansion of benign appearing plasma cells which synthesised, and usually secreted, a marker protein comprising a heavy chain fragment of $\operatorname{IgA}$, devoid of light chains. Analysis of the Fc $\alpha$ fragment found in serum, urine and intestinal fluid revealed that it bound secretory component (SC), providing the first evidence for the binding site of SC to the IgA dimer. Left untreated, $\alpha C D$ progresses to a frankly invasive intestinal lymphoma. The discovery of $\alpha C D$, has provided a unique and important opportunity to study the natural history of a B cell lymphoma as well as offering the prospect of early diagnosis by detection of the marker protein and of cure..$^{\text {th }}$

The molecular analysis of immune and inflammatory events at the mucosal surface in human beings has been greatly enhanced by the improved access to tissue provided by developments in fibreoptics and in ultrasound, microassay systems including HPLC, fluorimetry, monoclonal antibodies and DNA probes, and the use of recombinant DNA technology to engineer micro-organisms not only to produce large quantities of previously unavailable natural peptides in pure form but also to create recombinant vaccines for oral immunisation against intestinal infection and infestation. Besredka's vision of oral vaccines is now being realised.

\section{Division of Clinical Sciences,}

John Curtin School of Clinical Research, Australian National University,

Canberra.

\section{References}

1 Besredka A. De la vaccination contra les états typhoid par la voic buccale. Ann Inst Pasteur 1919; 33: 882.

2 Crabbé PA, Heremans JF. Etude immunohistochemique des plasmocytes de la muquese intestinale humaine normale. Rev Franç Etudes Clin biol 1966; 11: 484-92.

3 Tomasi TB. Structure and function of mucosal antibodies. Ann Rev Med 1970; 21: 281-98.

4 Doc WF, Henry K. Hobbs JR, Dowling RH. Alpha chain disease. $Q J$ Med 1970; 39: 619 .

5 Brandtzacg P. Role of J chain and secretory component in receptor-mediated glandular and hepatic transport of immunoglobulins in man. Scand J Immunol 1985; 22: 111-46.

6 Crabbé PA, Nash DR. Bazin H. Eyssen H, Heremans JF. Immunohistochemical observations on lymphoid tissue from conventional and germ-free mice. Lab Invest 1970; 22: 448-57.

7 Bland PW, Warren LG. Antigen presentation by epithelial cells of the rat small intestine. I Kinetics. antigen specificity and blocking by anti la antisera. Immunology 1986; 58: 1-7.

8 Mayer L, Schlien R. Evidence for function of Ia molecules on gut epithelial cells in man. J Exp Med 1987; 166: 1471-83.

9 Sollid LM, Brandtzaeg P, Kvale D, et al. T cell epithelium interactions in relation to gut immunity. Monogr Allergy 1988; 24: 60-65.

10) Owen RL, Jones AL. Epithelial cell specialization within human Peyer's patches: An ultrastructural study of intestinal lymphoid follicles. Gastroenterology 1974; 66: 189-203.

11 Owen RL. Sequential uptake of horseradish peroxidase by lymphoid follicle epithelium of Peyer's patches in the normal unobstructed mouse intestine: An ultrastructural study. Gastroenterology 1977; 72: 440-5.

12 Spalding DM, Koopman WJ, Eldridge JH, McGhee JR, Stcinman RM. Accessory cells in murine Peyer's patch. I Identification and Enrichment of a functional dendritic cell. J Exp Med 1983; 157: 1646-59.

13 Pavli P, Hume DA, Doe WF. Isolation and enrichment of human colonic antigen-presenting dendritic cells (DCs). Gastroenterology 1989; 5: A385.

14 Stevens SK, Weissman IL, Butcher EC. Differences in the migration of $B$ and $T$ lymphocytes: organ-selective localization in vivo and the role of lymphocyte-endothelial cell recognition. J Immunol 1982; 128: 844-51. 
15 Mestecky J, McGhee JR. Immunoglobulin A (IgA): Molecular and cellular interactions involved in $\operatorname{IgA}$ Biosynthesis and Immune response. Adv Immunol 1987; 40: 153-245.

16 Husband A. Gowans JL. The origin and antigendependent distribution of $\operatorname{IgA}$-containing cells in the intestine. $J$ Exp Med 1978; 148: 1146-60.

17 Pierce NF, Cray WC Jr. Determinants of the localization, magnitude and duration of a specific mucosal IgA plasma cell response in enterically immunised rats. $J$ Immunol 1982; 128: 1311-5.

18 Ferguson A, Parrott DMV. The effect of antigen deprivation on thymus dependent and thymus independent lymphocytes in the small intestine of the mouse. Clin Exp Immunol 1972; 17: 477-88.

19 Halpern MS, Koshland ME. Novel subunit in secretory IgA. Nature (Lond) 1970; 228: 1276-8.

20 Zikan J, Novotny J, Trapane TL, et al. Secondary structure of the immunoglobulin J chain. Proc Natl Acad Sci USA 1985; 8: 5905-9.

21 Fujiyama Y, Kobayashi K, Senda S, et al. A novel $\operatorname{IgA}$ protease from Clostridium sp. capable of cleaving $\operatorname{Ig} \mathrm{A}_{1}$ and $\operatorname{IgA} \mathrm{A}_{2} \mathrm{~A} 2 \mathrm{~m}(1)$ allotype but not $\operatorname{Ig} \mathrm{A}_{2} \mathrm{~A} 2 \mathrm{~m}(2)$ allotype paraproteins. J Immunol 1985; 134: 573-6.

22 Heremans JF, Bazin H. Antibodies induced by local antigenic stimulation of mucosal surfaces. Ann NY Acad Sci 1972; 190: 268-75.

23 Ogra PL, Karzon DT. Poliovirus antibody response in serum and nasal secretions following intranasal inoculation with inactivated poliovaccine. J Immunol 1969; 102: $15-23$.

24 Colten $\mathrm{H}$, Bienenstock $\mathrm{J}$. Lack of $\mathrm{C} 3$ activation through classical or alternate pathways by human secretory IgA anti-blood-group-A antibody. In: Mestecky J, Lawton AR, eds. The Immunoglobulin A system New York: Plenum, 1974; 45: 305.

25 Fanger MW, Goldstine SN, Shen L. Cytofluorographic analysis of receptors for $\operatorname{IgA}$ on human polymorphonuclear cells and monocytes and the correlation of receptor expression with phagocytosis. Mol Immunol 1983; 20: 1019-27.

26 Tagliabue A, Boraschi D, Villa L, et al. IgA-dependent cell-mediated activity against enteropathogenic bacteria: distribution, specificity and characterisation of the effector cells. J Immunol 1984; 133: 988-92.

27 Nagura H, Nakane PK. Brown WR. Translocation of dimeric IgA through neoplastic colon cells in vitro. $J$ Immunol 1979; 123: 2359-68.

28 Tomana M, Phillips JO, Kulhavy R, Mestecy J. Carbohydrate-mediated clearance of secretory $\operatorname{IgA}$ from the circulation. Mol Immunol 1985; 22: 887-92.

29 Cebra J, Komisar JL, Schweitzer PA. $C_{H}$ isotype "switching" during normal B-lymphocyte development. Ann Rev Immunol 1984; 2: 493- 548.

30 Elson CO, Heck JA, Strober W. T cell regulation of murine IgA synthesis. J Exp Med 1979; 149: 632-43.

31 Kawanishi H, Saltzman L, Strober W. Mechanisms regulating IgA class-specific immunoglobulin production in murine gut-associated lymphoid tissues II. Terminal differentiation of postswitch sIgA-bearing Peyer's patch B cells. J Exp Med 1983; 158: 649-69.

32 Kiyono H, Cooper MD, Kearney JF, et al. Isotype specificity of helper T cell clones. Peyer's patch Th cells preferentially collaborate with mature IgA B cells for IgA responses. J Exp Med 1984; 159: 798-811.

33 Kiyono H, Mostellar-Barnum LM, Pitts AM. Williamson SI, Michalck SM, McGhec JR. Isotypespecific immunoregulation: IgA binding factors produced by $\mathrm{Fc} \alpha$ receptor positive $\mathrm{T}$ cell hybridomas regulate IgA responses. $J$ Exp Med 1985; 161: 731-47.

34 Ishizaka K. Regulation of IgE synthesis. Ann Rev Immunol 1984; 2: 159-82.

35 Suzuki I, Kitamura J, Kiyono H, et al. Isotype-specific immuno-regulation. Evidence for a distinct subset of $\mathrm{T}$ contrasuppressor cells for $\operatorname{IgA}$ responses in murine Peyer's patches. J Exp Med 1986; 164: 501-16.

36 André C, Heremans JF, Vaerman JP, Cambiasco CL. A mechanism for induction of immunological tolerance by antigen feeding: antigen-antibody complexes. $J$ Exp Med 1975; 142: 1509-19.

37 Kagnoff MF. Effects of antigen-feeding on intestinal and systemic immune responses. III. Antigen-specific serum-mediated suppression of humoral antibody responses after antigen feeding. Cell Immunol 1978; 40: 186-203.

38 Zeitz M, Greene WC, Peffer NJ, James SP. Lymphocytes isolated from the intestinal lamina propria of normal nonhuman primates have increased expression of genes associated with $\mathrm{T}$ cell activation. Gastroenterology 1988; 94: 647-55.

39 Shanahan F, Brogan M, Targan S. Human mucosal cytotoxic effector cells. Gastroenterology 1987; 92: 1951-7.

40) Hogan PG, Hapel AJ, Doe WF. Lymphokine-activated and natural killer cell activity in human intestinal mucosa. J Immunol 1985; 135: 1731-8.

41 Fiocchi C. Tubbs RR. Youngman KR. Human intestinal mucosa mononuclear cells exhibit lymphokine-activated killer cell activity. Gastroenterology 1985; 88: 625-37.

42 Phillips JH, Lanier LL. Lectin-dependent and anti CD-3 induced cytotoxicity are preferentially mediated by peripheral blood cytotoxic $\mathrm{T}$ lymphocytes expressing Lcu-7 antigen. J Immunol 1986; 136: 1579-8.5.

43 Shanahan F, Deem R. Nayersina R, Leman B, Targan S. Human mucosal T-cell cytotoxicity. Gastroenterology 1988; 94: 960-7.

44 Seligman A, Hurez D, Mihacsco D, et al. Alpha chain disease: a new immunoglobulin abnormality. Science 1968: 162: 1396-7.

45 Doe WF, Hobbs J, Henry K, et al. Five cases of alpha chain disease. Gut 1972; 13: 947-57.

46 WHO Alpha chain disease and related small intestinal lymphome. Revue Generale, Arch Franç Mal Appar Dig 1976; 65: 591-607. 